\title{
IMPACT OF DEMOGRAPHIC FACTORS ON ENVIRONMENTALLY CONSCIOUS PURCHASE BEHAVIOR
}

\author{
Igor Trandafilović ${ }^{1}$, Vesna Conić ${ }^{2}$, Aleksandra Blagojević ${ }^{3}$
}

\begin{abstract}
Summary
Over the last years, a number of papers have been published on the topic of the influence of different factors on the environmentally conscious behavior of consumers. It can be noted that interest in the influence of demographic factors on this type of behavior in these papers is diminishing. However, the published papers did not provide a unique answer on this topic. The goal of this paper is to examine the correlation between demographic factors and environmentally conscious purchase behavior using the method of meta-analysis and CMA software. In line with this statistical method, studies that examined the influence of demographic factors on environmentally conscious purchase behavior have been taken into account. Among these, only the studies that published Pearson correlation coefficient have been selected. This way, it was possible to aggregate the samples of these studies and to repeat the testing of the hypothesis that demographic factors influence the environmentally conscious purchase behavior. Results of this analysis provide some proof of this correlation, but also call for an expanded research to deal with this topic in more details.
\end{abstract}

Key words: demographic factors, environmentally consumers behavior, meta-analysis.

JEL: $M 31, Q 01, Q 50$

\section{Introduction}

The issue of sustainability is related to the preservation of natural resources and the environment today so that future generations will be able to meet their needs (WCED, 1986). Since the 60s of last century environmental disasters are becoming more frequent and since then arise awareness among people that the development has its limits (Ekins, 1992). Some of the problems are air pollution, soil degradation, water pollution (Marinković

1 Igor Trandafilović, Ph.D., Associate Professor, John Naisbitt University, Faculty of Management Zaječar, Park šuma Kraljevica bb, 19000 Zaječar, Republic of Serbia, Phone: +381 6005995 98, E-mail: tranfi@ptt.rs

2 Vesna Conić, Ph.D., Research Fellow, Mining and Metallurgy Institute Bor, Zeleni bulevar 35, 19210 Bor, Republic of Serbia, Phone: +381 304541 01, E-mail: vesna.conic@irmbor.co.rs

3 Aleksandra Blagojević, M.Sc., John Naisbitt University, Faculty of Management Zaječar, Park šuma Kraljevica nn, 19000 Zaječar, Republic of Serbia, Phone:+381 631067 891, E-mail: alex.blago.11@gmail.com

EP 2017 (64) 4 (1365-1377) 
et al., 2014). To solve these problems started development of new technologies, changes in production processes, changes in strategies, modification of products and services (Kotler, 2011). Also, new international and national legislations was introduced (e.g. WCED, 1986) as well as various programs and ways to support sustainable development (e.g. Nikolić et al., 2017). The contribution of the theory lies in the development of scientific disciplines such as green marketing which "consists of all activities designed to generate and facilitate any exchanges intended to satisfy human needs or wants, such that the satisfaction of these needs and wants occurs, with minimal detrimental impact on the natural environment" (Polonsky, 1994).

In making purchasing decisions, consumers take into account the effect of this purchasing on the environment (Kilbourne, 1998). Research of the European Commission (Eurobarometer), conducted in 2012, found that $80 \%$ of citizens of the European Union takes into account the effects on the environment caused by products they buy, while a quarter buys green products (Euractiv, 2013). In the USA, sales of organic food and beverages have grown from 1 billion USD in 1990 to 24.8 billion USD in 2009 and within the organic food consumption market, organic condiments have shown the strongest overall growth: $17 \%$ in sales to account for 930 million USD of the industry's sales (Brandongaille, 2015). Conducted survey in Serbia toward purchasing of organic food brought finding that $45.3 \%$ of respondents occasionally purchase while $13.8 \%$ of respondents are regular consumers (Vehapi, Dolićanin, 2016).

Environmentally conscious, green consumers, are buying products that come from the production processes which are not harmful to the environment, such as an organic food production, do not contain toxic substances nor substances which damage the ozone, are manufactured from recycled materials, can be recycled (Ward, 2017). For companies, these consumers are a chance for increasing its market share through production and sales of products and services that are environmentally friendly (Schlegelmilch et al., 1996).

The Greens are also interesting to scholars, and a large number of studies have been directed to study the behavior of consumers who are environmentally conscious (Webster, 1975; Van Liere, Dunlap, 1981; Straughan, Roberts, 1999; Kim, Choi, 2005). However, Diamantopoulos et al. (2003) noted that in recent years a small number scientific studies take into account or reports on demographic factors. Considering that the demographic data are collecting during each survey, this is a very interesting fact. Also, when companies are doing market research for their own purposes they always include these factors and take them into account in the analysis (Diamantopoulos et al., 2003; McDonald, Dunbar, 1998).

Based on all of the foregoing, it is interesting to examine whether there is a correlation between demographic factors and the environmentally conscious consumer behavior. One of the ways that we can come up with an answer to this question is that we start from the published papers on this topic, use reported results and use meta-analysis to re-test the hypothesis and examine whether there is a correlation between demographic factors and environmentally conscious consumer behavior or not. 


\section{Literature review}

Environmentally conscious consumers are also known as green and ethical consumers (Chan, 2001). These consumers in buying process are "consistently seek product or company information and attempt to integrate a variety of environmental and or societal influences with their buying behavior" (McEachern, McClean, 2002).

Many studies have investigated and found a connection between demographic factors and environmentally conscious consumer behavior (Webster, 1975; Straughan, Roberts, 1999; Mostafa, 2007; Florenthal, Arling, 2011). However, McEachern and McClean (2002) argued that despite the increased papers on this topic they are relatively underresearched. This is supported by the fact that the results of these studies are not consistent and the differences can obtain because of a variety of ways and methods used in research, a variety of the number of subjects, the differences between cultures, economies. Among demographic factors, most often examined are age, gender and level of education (Webster, 1975; Straughan, Roberts, 1999; Diamantopoulos et al., 2003).

Age as an independent variable was the subject of research in many studies (Abruthnot, Lingg, 1975; Ostman, Parker, 1987; Straughan, Roberts, 1999; Diamantopoulos et al., 2003). There is a general belief that younger people are more sensitive to environmental issues and therefore more likely is that they will be environmentally conscious consumers and will have positive attitudes about environmentally conscious behavior in consumption. This belief has been confirmed in some papers (Weigel, 1977; Diamantopoulos et al., 2003) while others came to the opposite conclusion (Roberts, Straughan, 1999). Also, there are studies which concluded that there is no correlation between age and environmentally conscious behavior (Ostman, Parker, 1987; Van Lier, Dunlap, 1981).

Hence, one cannot say with certainty that there is a positive or negative correlation between age and the ecologically conscious consumer behavior, nor that this correlation does not exist. For this reason, it is interesting to examine this correlation.

When it comes to education, the belief is that people with higher education are more likely to behave in an environmentally conscious manner. Some studies have confirmed positive correlations (Weigel, 1977; Ostman, Parker, 1987) while some reported that there is no significant correlation between education and green purchase behavior (Diamantopoulos et al., 2003). Therefore, on this subject, there is no unambiguous conclusion. Considering that this is another demographic factor that should be examined.

Many studies have confirmed that women are more environmentally conscious buyers compared to men and have a higher level of awareness and positive attitudes when it comes to environmental issues (Webster, 1975; Bloceker, Lee, 1997; Roberts, Straughan, 1999; Florenthal, Arling, 2011). Only Mostafa (2007) has come to opposite conclusion which is explained by cultural differences of the country where the research was conducted.

Common for all studies is the difference in samples (number of subjects, cultural differences, social differences), in used methods but also the fact that each considers different factors. 
The goal of this paper is to try to overcome previously mentioned issues and to examine the influence of demographic factors on the environmentally conscious consumer behavior.

\section{Method of research}

Meta-analysis is a research technique that is often used in behavioral sciences, but there is almost no area of science which cannot be applied (Morris, 2008). It is based on the analysis of the results obtained during the previous research, according to obtained results brings a conclusion on the admissibility previous findings (Bartolucci, 2009).

To get to the data that will be analyzed, a few steps need to be done. It is necessary to choose the scientific field which papers belong, to choose the criteria for selection of scientific papers. After that then it is necessary to choose reported indicator or reported result which will be further analyzed (Glass, 1976; Ilić, 2009).

The first step in this research was the selection of published scientific papers based on the subject of their research. For this purpose, we used a web browser and e-library (Kobson) and combinations of words environmentally conscious consumer, environmentally purchase, and green consumers. From results, we were selecting the published papers.

The second step we selected only papers that examined the correlation between demographic factors and environmentally consumers. The further step included a selection of those papers which reported, as a result, Pearson's correlation coefficient to have comparable results.

For data processing software Comprehensive meta-analysis (CMA) is used.

In line with correlation coefficient, selected papers examined the correlation between demographic factors, as follows age, education, and gender, as the independent variable and environmentally conscious consumer behavior (Lovrić, 2009):

$$
H_{0}: \rho=0
$$

Since this is the method of meta-analysis heterogeneity have to be taken into account, or there is no heterogeneity (Bartolucci, 2009):

$$
H_{0}: Q=0
$$

Where $\mathrm{Q}$ has a chi-square distribution and is determined depending on a critical value of a certain degree of freedom and $\mathrm{p}>0.05$ (NIST SEMATECH, 2017).

\section{Results}

Diamantopoulos et al. (2003) and Weigel (1977) reported a negative correlation between age and the environmentally conscious consumer behavior while Roberts and Straughan (1999) and Ostman and Parker (1987) had the opposite conclusion. The results of these studies are presented in Table 1 . The results of the meta-analysis are given in Table 2. 
Table1. The studies used for the analysis: age as independent variable

\begin{tabular}{|l|r|r|}
\hline \multicolumn{1}{|c|}{ Study } & Correlation & \multicolumn{1}{c|}{ n } \\
\hline Weigel (1977) & -0.24 & 44 \\
\hline Ostman, Parker (1987) & 0.03 & 329 \\
\hline Roberts, Straughan (1999) & 0.16 & 235 \\
\hline Diamantopoulos et al. (2003) & -0.28 & 1,627 \\
\hline
\end{tabular}

Source: Author's computation, studies listed in table

Table 2. The results of the meta-analysis: age as independent variable

\begin{tabular}{|c|c|c|c|c|c|c|c|}
\hline \multirow[t]{2}{*}{ Model } & \multirow{2}{*}{\multicolumn{2}{|c|}{$\begin{array}{l}\text { Study name } \\
\text { Correlation }\end{array}$}} & \multicolumn{5}{|c|}{ Statistics for each study } \\
\hline & & & $\begin{array}{l}\text { Lower } \\
\text { limit }\end{array}$ & $\begin{array}{l}\text { Upper } \\
\text { limit }\end{array}$ & Z-Value & p-Value & \\
\hline & \multicolumn{2}{|c|}{ Weigel (1977) } & -0.240 & -0.501 & 0.061 & -1.567 & 0.117 \\
\hline & \multicolumn{2}{|c|}{ Ostman, Parker (1987) } & 0.030 & -0.078 & 0.138 & 0.542 & 0.588 \\
\hline & \multicolumn{2}{|c|}{\begin{tabular}{|l|} 
Roberts, Straughan \\
$(1999)$
\end{tabular}} & 0.157 & 0.030 & 0.279 & 2.411 & 0.016 \\
\hline & \multicolumn{2}{|c|}{\begin{tabular}{|l|}
$\begin{array}{l}\text { Diamantopoulos et al. } \\
(2003)\end{array}$ \\
\end{tabular}} & -0.275 & -0.319 & -0.229 & -11.375 & 0.000 \\
\hline Fixed & & & -0.188 & -0.227 & -0.147 & -8.949 & 0.000 \\
\hline \multicolumn{3}{|l|}{ Random } & -0.077 & -0.314 & 0.169 & -0.610 & 0.542 \\
\hline \multicolumn{8}{|c|}{ Heterogeneity and Tau-squared } \\
\hline \multirow{2}{*}{ Fixed } & Q-value & $\operatorname{df}(Q)$ & I-squared & $\begin{array}{c}\text { Tau } \\
\text { Squared } \\
\end{array}$ & St. Error & Variance & Tau \\
\hline & 57.874 & 3 & 94.816 & 0.057 & 0.060 & 0.004 & 0.239 \\
\hline
\end{tabular}

Source: Authors' computation, CMA software

Figure 1. Forest plot for the results of the meta-analysis (age as independent variable)

Correlation and $95 \% \mathrm{CI}$

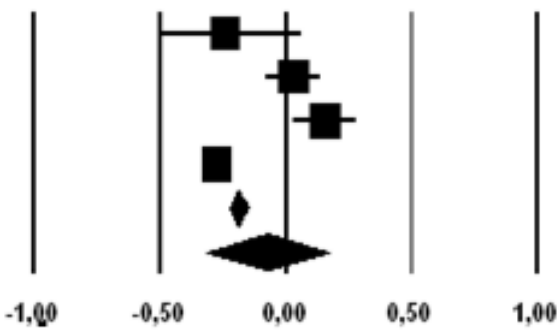

Favours A

Favours B

Source: CMA software 
Since the result is $\mathrm{Q}=57.874$ (for $\mathrm{p}<0.05$ and $\mathrm{df}=3, \mathrm{Q}=7.815$ ) we reject the null hypothesis because there is a statistically significant difference among studies. The obtained sample is heterogeneous. This is indicated and by I-squared $\left(\mathrm{I}^{2}\right)$, which means that $94.816 \%$ is the level of heterogeneity. If we consider a fixed model, we can see that the correlation is negative and weak $(r=-0.188)$ but statistically significant $(\mathrm{p}<0.05)$.

All studies that have examined the correlation of education (as independent variables) and environmentally conscious behavior reported a positive correlation as a result. They are presented in Table 3. The results of the meta-analysis are given in Table 4.

Table 3. The studies used for the analysis: education as independent variable

\begin{tabular}{|l|r|r|}
\hline \multicolumn{1}{|c|}{ Study } & \multicolumn{1}{c|}{ Correlation } & \multicolumn{1}{c|}{ n } \\
\hline Webster (1975) & 0.01 & 231 \\
\hline Weigel (1977) & 0.42 & 44 \\
\hline Ostman, Parker (1987) & 0.20 & 327 \\
\hline Cerjak et al. (2010) & 0.14 & 600 \\
\hline
\end{tabular}

Source: Author's computation, studies listed in table

Table 4. The results of the meta-analysis: education as independent variable

\begin{tabular}{|c|c|c|c|c|c|c|c|}
\hline \multirow[t]{2}{*}{ Model } & \multirow{2}{*}{\multicolumn{2}{|c|}{$\begin{array}{l}\text { Study name } \\
\text { Correlation }\end{array}$}} & \multicolumn{5}{|c|}{ Statistics for each study } \\
\hline & & & $\begin{array}{c}\text { Lower } \\
\text { limit }\end{array}$ & $\begin{array}{l}\text { Upper } \\
\text { limit }\end{array}$ & Z-Value & p-Value & \\
\hline & \multicolumn{2}{|c|}{ Webster (1975) } & 0.010 & -0.119 & 0.139 & 0.151 & 0.880 \\
\hline & \multicolumn{2}{|c|}{ Weigel (1977) } & 0.420 & 0.141 & 0.637 & 2.867 & 0.004 \\
\hline & \multicolumn{2}{|c|}{ Ostman, Parker (1987) } & 0.200 & 0.094 & 0.302 & 3.649 & 0.000 \\
\hline & \multicolumn{2}{|c|}{ Cerjak et al. (2010) } & 0.140 & 0.061 & 0.218 & 3.443 & 0.001 \\
\hline Fixed & & & 0.142 & 0.086 & 0.197 & 4.941 & 0.000 \\
\hline \multicolumn{3}{|l|}{ Random } & 0.154 & 0.044 & 0.261 & 2.725 & 0.006 \\
\hline \multicolumn{8}{|c|}{ Heterogeneity and Tau-squared } \\
\hline \multirow[t]{2}{*}{ Fixed } & Q-value & $\operatorname{df}(Q)$ & I-squared & $\begin{array}{c}\text { Tau } \\
\text { Squared }\end{array}$ & St. Error & Variance & Tau \\
\hline & 8.998 & 3 & 66.659 & 0.008 & 0.011 & 0.000 & 0.089 \\
\hline
\end{tabular}

Source: Authors' computation, CMA software 
Figure 2. Forest plot for the results of the meta-analysis (education as independent variable)

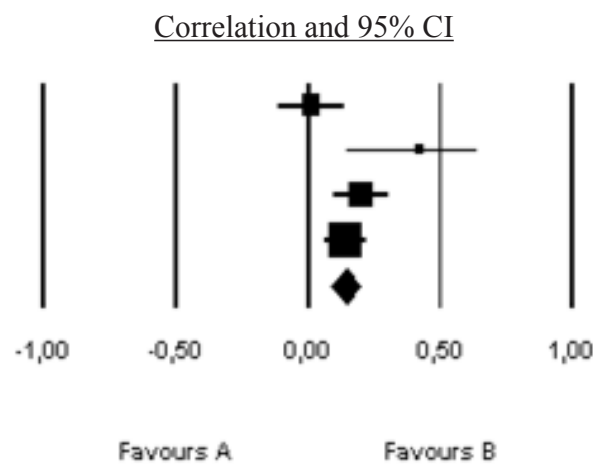

Source: CMA software

The result is $\mathrm{Q}=8.998$ (for $\mathrm{p}<0.05$ and $\mathrm{df}=3, \mathrm{Q}=7.815$ ). However, if we see Figure 2 we will see that one study differs. Weigel (1977) has reported higher result than others $(\mathrm{r}=0.42)$ but study has no great significance $(n=44)$, therefore calculations will be repeated without it. The results of this analysis are given in Table 5, for clarification results are additional named as the second step.

Table 5. The results of the meta-analysis: education as independent variable, second step

\begin{tabular}{|c|c|c|c|c|c|c|c|}
\hline \multirow[t]{2}{*}{ Model } & \multirow{2}{*}{\multicolumn{2}{|c|}{$\begin{array}{l}\text { Study name } \\
\text { Correlation }\end{array}$}} & \multicolumn{5}{|c|}{ Statistics for each study } \\
\hline & & & $\begin{array}{c}\text { Lower } \\
\text { limit }\end{array}$ & $\begin{array}{l}\text { Upper } \\
\text { limit }\end{array}$ & Z-Value & p-Value & \\
\hline & \multicolumn{2}{|c|}{ Webster (1975) } & 0.010 & -0.119 & 0.139 & 0.151 & 0.880 \\
\hline & \multicolumn{2}{|c|}{ Ostman, Parker (1987) } & 0.200 & 0.094 & 0.302 & 3.649 & 0.000 \\
\hline & \multicolumn{2}{|c|}{ Cerjak et al.(2010) } & 0.140 & 0.061 & 0.218 & 3.443 & 0.001 \\
\hline Fixed & & & 0.132 & 0.074 & 0.188 & 4.487 & 0.000 \\
\hline \multicolumn{3}{|l|}{ Random } & 0.124 & 0.029 & 0.218 & 2.541 & 0.011 \\
\hline \multicolumn{8}{|c|}{ Heterogeneity and Tau-squared } \\
\hline \multirow[t]{2}{*}{ Fixed } & Q-value & $\operatorname{df}(Q)$ & I-squared & $\begin{array}{c}\text { Tau } \\
\text { Squared }\end{array}$ & St. Error & Variance & Tau \\
\hline & 5.062 & 2 & 60.489 & 0.004 & 0.007 & 0.000 & 0.066 \\
\hline
\end{tabular}

Source: Authors' computation, CMA software 
Figure 3. Forest plot for the results of the meta-analysis (education as independent variable) second step

\section{Correlation and 95\%CI, Fixed}

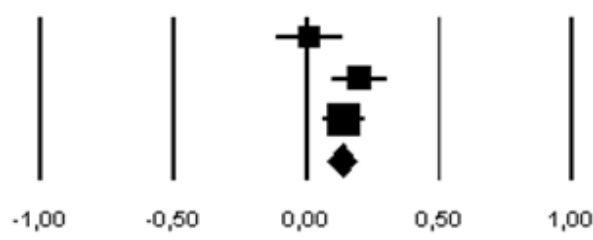

Source: CMA software

The result is $\mathrm{Q}=5.062$ (for $\mathrm{p}<0.05$ and $\mathrm{df}=2, \mathrm{Q}=5.991$ ) and we can say we have homogeneity. The correlation between education and environmental behavior exist, it is very weak $(\mathrm{r}=$ $0.13)$ and statistically significant $(\mathrm{p}<0.05)$.

A list of studies that have been taken into account for examination of the correlation of gender (as independent variables) and environmentally conscious behavior as well as reported results are given in Table 6. In all cases result are related to female. In all cases, scholars have come to the results which indicate that women as consumers are more environmentally conscious compared to men. The results of the meta-analysis are given in Table 7.

Table 6. The results of the meta-analysis: gender as independent variable

\begin{tabular}{|l|r|r|}
\hline \multicolumn{1}{|c|}{ Study } & Correlation & \multicolumn{1}{c|}{ n } \\
\hline Webster (1975) & 0.01 & 231 \\
\hline Bloceker, Lee (1997) & 0.13 & 1,557 \\
\hline Roberts, Straughan (1999) & 0.14 & 235 \\
\hline Florenthal, Arling (2011) & 0.10 & 101 \\
\hline
\end{tabular}

Source: Author`s computation, studies listed in table

Table 7. The results of the meta-analysis: gender as independent variable

\begin{tabular}{|l|l|r|r|r|r|r|}
\hline \multirow{2}{*}{ Model } & \multirow{2}{*}{ Study name } & \multicolumn{5}{|c|}{ Statistics for each study } \\
\cline { 3 - 8 } & & Correlation & Lower limit & Upper limit & Z-Value & p-Value \\
\hline & Webster (1975) & 0.011 & -0.118 & 0.140 & 0.166 & 0,868 \\
\hline & Bloceker, Lee (1997) & 0.130 & 0.081 & 0.179 & 5.154 & 0,000 \\
\hline & Roberts,Straughan (1999) & 0.136 & 0.008 & 0.259 & 2.084 & 0,037 \\
\hline & Florenthal, Arling (2011) & 0.100 & -0.097 & 0.290 & 0.993 & 0,321 \\
\hline Fixed & & 0.117 & 0.074 & 0.158 & 5,380 & 0,000 \\
\hline Random & & 0,117 & 0.074 & 0.158 & 5.380 & 0.000 \\
\hline \multicolumn{7}{|l|}{ Heterogeneity and Tau-squared } \\
\hline
\end{tabular}




\begin{tabular}{|c|c|c|c|c|c|c|c|}
\hline \multirow{2}{*}{ Fixed } & Q-value & $\operatorname{df}(Q)$ & I-squared & $\begin{array}{c}\text { Tau } \\
\text { Squared }\end{array}$ & St. Error & Variance & Tau \\
\hline & 2.974 & 3 & 0.000 & 0.000 & 0.003 & 0.000 & 0.000 \\
\hline
\end{tabular}

Source: Authors' computation, CMA software

Figure 4. Forest plot for the results of the meta-analysis (education as independent variable)

\section{Correlation and $95 \% \mathrm{CI}$}

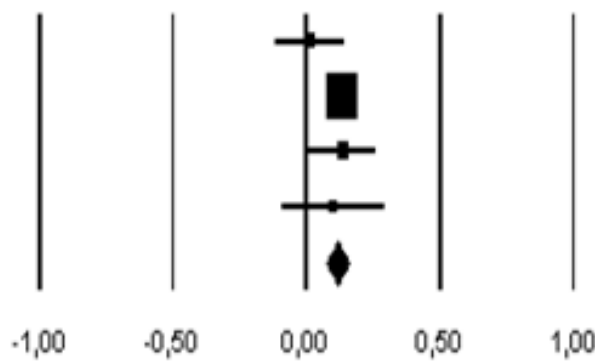

Source: CMA software

The results $\mathrm{Q}=2.974$ (for $\mathrm{p}<0.05$ and $\mathrm{df}=3, \mathrm{Q}=7.815$ ) means that homogeneity is confirmed. The correlation between the gender (female) and the environmentally behavior exist, it is a very weak $(r=0.12)$ and statistically significant $(\mathrm{p}<0.05)$.

\section{Discussion of results}

At the beginning this study we started from the question whether there is a correlation between demographic factors and the environmentally conscious consumer behavior. The results obtained in this paper, based on studies that were used, indicate that we need to be careful with generalizing conclusions.

In a case of age, first of all, the result is heterogeneity. Results obtained indicate the very high level of heterogeneity $(94.816 \%)$ and suggested that samples from primary studies are very different. Based on the obtained results we cannot confirm the existence of negative correlation (as a result from the fixed model: $\mathrm{r}=-0.188$ at $\mathrm{p}<0.05$ ) between age and environmentally consumer behavior.

Analysis of correlation between education and environmentally consumer behavior pointed out the importance of selected studies. In the second step, when one study was excluded from the analysis, we came to a homogeneous sample. On the possibility of such cases indicates the literature on meta-analysis (Bartolucci, 2009). The obtained results suggest that there is a weak positive correlation (as a result from the fixed model: $\mathrm{r}=0.132$ at $\mathrm{p}<$ 0.05 ) between education and environmentally consumer behavior. To the same conclusion came Webster (1975), Ostman, Parker (1987) and Cerjak et al. (2010). 
In a case of correlation between gender (female) and environmentally consumer behavior we obtain result that there is positive correlation (as a result from fixed model: $\mathrm{r}=0.117$ at $\mathrm{p}$ $<0.05$ ) and to the same conclusion came Webster (1975), Bloceker, Lee (1997), Roberts, Straughan (1999) and Florenthal, Arling (2011).

\section{Conclusion}

Based on the results of this paper research, we can say that the correlation between some demographic factors and environmentally friendly consumer behavior exist but also that we need to be careful with generalizing conclusions. The advantages of this research are that the samples can be integrated and hypotheses that are tested in primary studies repeated. However, we should not ignore the limitations of the method used as well as limitations came from primary studies concerning the number of participants, used method and other specifics.

The following limitations of this study refer to the method of selection. It is possible that because of the used database or a combination of the words some studies have not been taken into account. Same refers to the selected indicator.

The obtained results indicate the need for further and comprehensive as well as well-structured research of correlation and the impact of demographic factors on the environmentally conscious consumer behavior. However, the information obtained from this paper can certainly be a starting point for future research and useful for business based on the principles of sustainable development.

\section{Literature}

1. Bartolucci, A. (2009): Opis i tumačenje metodoloških i statističkih tehnika u metaanalizama, Biochemia Medica, vol.19, no. 2, pp. 127-136.

2. Blocker, T. J., Lee, E. D. (1997): Gender and Environmentalism: Results from the 1993 General Social Survey, Social Science Quarterly, University of Texas Press, vol. 78, issue 4, pp. 841-858.

3. Brandongaille (2015): 17 Important Organic Food Consumption Statistics, (available at: https://brandongaille.com/17-important-organic-food-consumption-statistics/)

4. Cerjak, M., Mesić, Ž., Kopić, M., Kovačić, D., Markovina, J. (2010): What motivates consumers to buy organic food - comparison of Croatia, Bosnia Herzegovina and Slovenia, Journal of Food Products Marketing, Jul-Sep, vol. 16 issue 3, pp. 278-292.

5. Chan, R. Y. (2001): Determinants of Chinese consumers' green purchase behavior, Psychology \& Marketing, vol. 18, no. 4, pp. 389-413.

6. Diamantopoulos, A. Schlegelmilch, B., Sinkovics, R., Bohlen, G. (2003): Can sociodemographics still play a role in profiling green consumers? A review of the evidence and an empirical investigation, Journal of Business Research, vol.56, pp. $465-480$. 
7. Ekins, P. (1992): Limits to growth' and 'sustainable development': grappling with ecological realities, Ecological Economics, vol. 8, pp. 269-288, Elsevier Science Publishers B.V., Amsterdam.

8. Euractiv (2013): Europeans 'confused by green claims': Survey (available at: https:// www.euractiv.com/section/science-policymaking/news/europeans-confused-bygreen-claims-survey/)

9. Florenthal, B., Arling, P. (2011): Do Green Lifestyle Consumers Appreciate Low Involvement Green Products?, Marketing Management Journal, vol. 21, issue 2, pp. $35-45$.

10.Glass, G. (1976): Primary, Secondary, and Meta-Analysis of Research, American Educational Research Association, vol. 5, issue 10, pp. 3-8.

11.Ilić, I. (2009): Meta-analiza, Acta Medica Medianae, vol.48, pp. 28-31.

12.Kilbourne, W. (1998): Green Marketing: A Theoretical Perspective, Journal of Marketing Management, vol. 14, issue 6, pp. 641-655.

13. Kim, Y., Choi, S. M. (2005): Green Marketing: An Attitudinal and Behavioral Analysis of Indian Consumers, Global Business Review, vol. 5, no.2, pp. 187-205.

14.Kotler, P. (2011): Reinventing Marketing to Manage the Environmental Imperative, Journal of Marketing, vol. 75 (July), pp.132-135. American Marketing Association ISSN: 0022-2429 (print), 1547-7185 (electronic).

15.Lovrić, M. (2009): Osnovi statistike, p. 261, Ekonomski fakultet, Univerzitet u Kragujevcu.

16.Marinković, V., Obradović, Lj., Bugarin, M., Stojanović, G. (2014): The imapct of polluted wastewater on water quality of the Bor river and water quality surrounding groundwater, Mining \& Metallurgy Engineering Bor, no. 3, pp.33-40.

17. McEachern M. G., McClean, P. (2002): Organic purchasing motivations and attitudes: are they ethical?, International Journal of Consumer Studies, vol. 26, no. 2, June, p. 85.

18. Morris, S. (2008): Book Review: Hunter, J. E., \& Schmidt, F. L. (2004). Methods of Meta-Analysis: Correcting Error and Bias in Research Findings (2nd ed.). Thousand Oaks, CA: Sage, Organizational Research Methods, vol. 11, no. 1, January, pp.184187.

19. Mostafa, M. (2007): Gender differences in Egyptian consumers' green purchase behavior: the effects of environmental knowledge, concern and attitude, International Journal of Consumer Studies, vol. 31, issue 3, May, pp. 220-229.

20.Nikolić, S. R., Vuković, P., Grujić, B. (2017): Measures to Support the Development of Organic Farming in the EU and Serbia, Economics of Agriculture vol. 1/2017, pp. 323-337.

21.NIST SEMATECH (2017): NIST/SEMATECH e-Handbook of Statistical Methods, (available at: http://www.itl.nist.gov/div898/handbook/eda/section3/eda3674.htm) 
22. Ostman, R. E., Parker, J. L. (1987): Impact of Education, Age, Newspapers, and Television on Environmental Knowledge, Concerns, and Behaviors, Journal of Environmental Education, vol. 19, issue 1, pp. 3-9.

23.Polonsky, M. J. (1994): A stakeholder theory approach to designing environmental marketing strategy, Journal of Business \& Industrial Marketing, vol. 10, no. 3. pp. 29-46

24. Roberts, J. A., Straughan, R. D. (1999): Environmental segmentation alternatives: a look at green consumer behavior in the new millennium, Journal of Consumer Marketing, vol. 16, pp. 558-575.

25.Schlegelmilch, B., Bohlen, B., Diamantopoulos, A.(1996): The link between green purchasing decisions and measures of environmental consciousness, European Journal of Marketing, vol. 30, no. 5, pp. 35-55.

26. Van Liere, K., Dunlap, R. (1981): The social bases of environmental concern: a review of hypotheses, explanations, and empirical evidence, Public Opinion Quarterly, vol. 44, no. 2, pp. 181-197.

27. Vehapi, S., Dolićanin, E. (2016): Consumer Behaviour on Organic Food: Evidence from the Republic of Serbia. Economics of Agriculture, vol. 3, pp.871-889

28. Ward, S. (2017): Stick to the Definition and Green Marketing Can Be Very Powerful, The Balance (available at: https://www.thebalance.com/green-marketing-2948347).

29. WCED (1986): Our Common Future, Chapter 2: Towards Sustainable Development (available at: http://www.un-documents.net/ocf-02.htm)

30. Webster, F. E. (1975): Determining the Characteristics of the Socially Conscious Consumer, The Journal of Consumer Research, vol. 2, December, pp. 188-196.

31. Weigel, H. R. (1977): Ideological and Demographic Correlates of Proecologicaly Behaviour, The Journal of Social Psychology, vol.103, pp. 39-47. 


\title{
UTICAJ DEMOGRAFSKIH FAKTORA NA EKOLOŠKI SVESNO PONAŠANJE POTROŠAČA
}

\author{
Igor Trandafilović, ${ }^{4}$ Vesna Conic ${ }^{5}$, Aleksandra Blagojevic ${ }^{6}$
}

\begin{abstract}
Rezime
Poslednjih godina, veliki je broj objavljenih radova na temu uticaja različitih faktora na ekološki svesno ponašanje potrošača. Ono što se može primetiti jeste da se sve manje ispituje uticaj demografskih faktora na ovo ponašanje. Do sada objavljeni radovi ne daju jedinstven odgovor po ovom pitanju i radi toga cilj ovog rada jeste da ispita korelaciju između demografskih faktora i ekološki svesnog ponašanja potrošača koristeći metod metaanalize i CMA program. U skladu sa ovom statističkom metodom, odabrane su studije koje su ispitivale uticaj demografskih faktora na ekološki svesno ponašanje potrošača. Među njima su odabrane one u kojima je kao rezultat objavljen Pirsonov koeficijent korelacije. Na ovaj način omogućeno je da se objedine uzorci iz prethodnih istraživanja i da se ponovi testiranje hipoteza o uticaju demografskih faktora na ekološki svesno ponašanje potrošača. Rezultati istraživanja ukazuju da ove korelacije postoje ali i da je potrebno opsežnije istraživanje koje bi obradilo ovu problematiku.
\end{abstract}

Ključne reči: demografski faktori, ekološki svesno ponašanje potrošača, meta-analiza JEL: $M 31, Q 01, Q 50$

4 Vanredni profesor, dr Igor Trandafilović, Univerzitet Džon Nezbit, Fakultet za menadžment Zaječar, Park šuma Kraljevica bb, 19000 Zaječar, Republika Srbija, Telefon: +381 60059 95 98, E-mail: tranfi@,ptt.rs

5 Naučni saradnik, dr Vesna Conić, Institut za rudarstvo i metalurgiju Bor, Zeleni bulevar 35, 19210 Bor, Republika Srbija, Telefon: +381 304541 01, E-mail: vesna.conic@irmbor.co.rs

6 Master ekonomije, Aleksandra Blagojević, Univerzitet Džon Nezbit, Fakultet za menadžment Zaječar, Park šuma Kraljevica bb, 19000 Zaječar, Republika Srbija, Telefon: +381631067 891, E-mail: alex.blago.11@gmail.com

EP 2017 (64) 4 (1365-1377) 
ECONOMICS OF

AGRICULTURE

\section{CONTENT}

1. Adriana Radosavac, Desimir Knežević

ECONOMIC IMPORTANCE OF USE

OF PESTICIDES IN WHEAT PRODUCTION . . . . . . . . . . . 1323

2. Berhe Gebregewergs, Muuz Hadush

DOES CLIMATE CHANGE AFFECT PRICE OF VEGETABLES:

EVIDENCE FROM TIGRAI, NORTHERN MOST ETHIOPIA. . . . .1335

3. Grujica Vico, Aleksandra Govedarica-Lučić, Zoran Rajić, Radomir Bodiroga, Ivan Mičić, Silvija Zec Sambol, Marija Mičić

MULTI ATTRIBUTE ASSESSMENT APPROACH

IN VEGETABLE PRODUCTION . . . . . . . . . . . . . . 1355

4. Igor Trandafilović, Vesna Conić, Aleksandra Blagojević

IMPACT OF DEMOGRAPHIC FACTORS ON

ENVIRONMENTALLY CONSCIOUS PURCHASE BEHAVIOUR. . .1365

5. Imre Milán Harcsa

STUDY ON THE POTENTIAL OF SUBCONTRACT

PALINKA DISTILLATION . . . . . . . . . . . . . . 1379

6. Jelena Andrašić, Vera Mirović, Nada Milenković, Branimir Kalaš, Miloš Pjanić

IMPACT OF TAKEOVER PROCESS ON EMPLOYEES -

EVIDENCE FROM FOOD, RETAIL AND FINANCIAL SECTOR . . .1393

7. Jelena Birovljev, Danilo Đokić, Bojan Matkovski, Žana Kleut

ECONOMIC PERFORMANCES OF AGRICULTURE

OF CEFTA AND FORMER CEFTA COUNTRIES . . . . . . . . . . 1413

8. Jelena Marković, Svetlana Stevović

SUSTAINABILITY OF CHEMICAL SOIL QUALITY

IN SOUTHERN MORAVA RIVER VALLEY

IN CORELLATION WITH THE FLOODING $\ldots \ldots \ldots \ldots \ldots$ 
9. Mile Peševski, Zoran Milovančević

THE CHANGES IN THE USAGE OF AGRICULTURAL LAND

IN EASTERN REGION OF REPUBLIC OF MACEDONIA

BETWEEN $1991-2030 \ldots \ldots$. . . . . . . . . . . . . . . . . . . . . . .

10. Odjuvwuederhie Emmanuel Inoni, 'Oraye Dicta Ogisi, Felix Odemero Achoja

PROFITABILITY AND TECHNICAL EFFICIENCY IN HOMESTEAD

CATFISH PRODUCTION IN DELTA STATE, NIGERIA . . . . . . . 1449

11. Olja Munitlak - Ivanović, Jovan Zubović, Petar Mitić

RELATIONSHIP BETWEEN SUSTAINABLE DEVELOPMENT AND

GREEN ECONOMY - EMPHASIS ON GREEN FINANCE

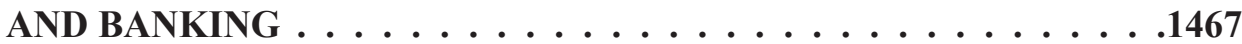

12. Petar Munćan, Dragica Božić

FARM SIZE AS A FACTOR OF EMLOYMENT AND INCOME

OF MEMBERS OF FAMILY FARMS . . . . . . . . . . . . . 1483

13. Rade Popović, Mira Kovljenić

EFFICIENCY OF WHEAT PRODUCTION ON FARMS

IN THE REPUBLIC OF SERBIA . . . . . . . . . . . . . . . . . . . . . . . . .

14. Radovan Damnjanović, Snežana Krstić, Milena Knežević, Svetislav Stanković,

Dejan Jeremić

THE DISCRIMINANT ANALYSIS APPLIED TO THE

DIFFERENTIATION OF SOIL TYPES . . . . . . . . . . . . 1513

15. Slavica Otović, Dunja Demirović, Kristina Košić, Aleksandra Vujko

FOSTERING ENTERPRENUERSHIP AT HIGH SCHOOLS:

A CASE OF RURAL AREAS IN VOJVODINA (SERBIA) . . . . . . .1523

16. Vladimir Ilić, Ivan Bauer, Anastazija Tanja Đelić, Aleksandar Nešković

INSTITUTIONAL SUPPORT FOR STRENGTHENING

ENTREPRENEURSHIP IN AGRICULTURAL PRODUCTION

OF THE REPUBLIC OF SERBIA . . . . . . . . . . . . . . . . . . . . . . . .

17. Boro Krstić, Zorica Vasiljević, Miroslav Nedeljković

INSURANCE CONTRACT AS THE BASIS FOR THE SAFETY OF

AGRICULTURAL PRODUCERS IN THE REPUBLIC OF SRPSKA • . 1555

18. Dejan Sekulić, Aleksandar Petrović, Vladimir Dimitrijević

WHO ARE WINE TOURISTS? AN EMPIRICAL INVESTIGATION

OF SEGMENTS IN SERBIAN WINE TOURISM . . . . . . . . . . . . . 
19. Milan Beslać, Ćorić Goran

FINANCIAL AND PRODUCTION ASPECTS OF GENETICALLY MODIFIED ORGANISMS $\ldots \ldots \ldots \ldots \ldots \ldots \ldots \ldots \ldots$

20. Mlađan Maksimović, Darjan Karabašević, Miodrag Brzaković, Pavle Brzaković THE EFFECTS RESULTING FROM THE APPLICATION OF THE CONCEPT OF THE SUSTAINABLE DEVELOPMENT OF RURAL TOURISM ON STARA PLANINA . . . . . . . . . . . . . . . .1595

21. Vesna Popović, Predrag Vuković, Milivoje Ćosić FOOD SAFETY AND QUALITY POLICY IN THE REPUBLIC OF SERBIA . . . . . . . . . . . . . . . . 1607

22. Radovan Pejanović, Danica Glavaš-Trbić, Mirela Tomaš-Simin PROBLEMS OF AGRICULTURAL AND RURAL DEVELOPMENT IN SERBIA AND NECESSITY OF NEW AGRICULTURAL POLICY . . . .1619

23. Saša Marković, Slavoljub Vujović, Aleksandar Damnjanović MARKETING AND HIGHER EDUCATION CONDITION IN SERBIA . . . . . . . . . . . . . . . . 1635

24. Semir Vehapi, Marina Milanović THE EFFECT OF MARKET ORIENTATION ON BUSINESS PERFORMANCE OF SERBIAN ORGANIC PRODUCERS . . . . . 1651

25. Suad Bećirović, Šemsudin Plojović, Enis Ujkanović, Senadin Plojović CHALLENGES AT STARTING AN AGRIBUSINESS IN THE HILLY MOUNTAINOUS REGIONS OF SOUTHWEST SERBIA . . . . . . . .1669

26. Vladimir Zakić, Vlado Kovačević, Jelena Damnjanović SIGNIFICANCE OF FINACIAL LITERACY FOR THE AGRICULTURAL HOLDINGS IN SERBIA . . . . . . . . . . 1687

27. Željko Bjelajac, Marijana Dukić Mijatović, Željko Vojinović PROTECTION OF LAND IN THE REPUBLIC OF SERBIA AND ECOLOGICAL SECURITY WITH REGARD TO STRATEGIC AND LEGAL FRAMEWORKS . . . . . . . . . .1703 